\title{
ANALISIS YURIDIS KEWENANGAN BUMN UNTUK MELAKUKAN MONOPOLI DAN ATAU PEMUSATAN KEGIATAN DALAM PERSPEKTIF KEPASTIAN HUKUM DAN KESEJAHTERAAN
}

Enggi Syefira Salsabila

Master of Law, University of Muhammadiyah Malang, Indonesia. madusyefira@gmail.com

\begin{abstract}
Pemerintah dalam perannya meningkatkan perekonomian Negara harus dikuti oleh campur tangan semua pihak. Salah satunya yaitu campur tangan BUMN yang merupakan perusahaan yang memiliki peran besar dalam memberikan sumber pendapatan Negara. Oleh karena itu BUMN memiliki kewenangan berupa monopoli dan pemusatan kegiatan terhadap suatu kegiatan usaha. Walaupun secara aturan yang ada bahwa kegiatan monopoli dan pemustaan kegiatan boleh dilakukan asalkan diperoleh dengan persaingan usaha yang sehat tetapi BUMN boleh melakukan monopoli dan pemustaan kegiatan tanpa harus melakukan sistem persaingan. Hal itu dapat dilakukan dengan adanya amanat Undang-undang. Adanya hak istimewa yang dimiliki BUMN tersebut, tercantum dalam pasal 51 Undang-undang no 5 tahun 1999 tentang larangan praktik monopoli dan persaingan usaha tidak sehat. Pasal 51 terbentuk dengan berlandaskan pasal 33 UUD 1945, dimana hal-hal yang berkaitan dengan hajat hidup orang banyak harus dikuasai oleh Negara. Penafsiran mengenai hak istimewa yang dimiliki BUMN ini kemudian ditafsirkan oleh beberapa pihak yaitu diantaranya pihak Komisi Pengawasan Persaigan Usaha (KPPU) dan Mahkamah Konstitusi (MK). Karena jika ditinjau kembali maksut dari isi pasal 51 masih memiliki arti yang sangat luas jika merujuk pada pengertian "penguasaan Negara" dan "menguasai hajat hidup orang banyak".
\end{abstract}

Kata Kunci: BUMN; Penguasaan negara; Menguasai hajat hidup orang banyak

\section{PENDAhuluan}

\section{Latar Belakang}

Negara dalam melaksanakan peranya sebagai pengatur perekonomian harus diikuti dengan kerjasama semua pihak. Salah satunya yaitu Badan Usaha Milik Negara (BUMN), dimana merupakan perusahaan nasional yang memiliki peran besar dalam meningkatkan sumber pendapatan Negara serta untuk meningkatkan kemakmuran rakyat. Dalam rangka meningkatkan kemakmuran rakyat yang sebesarbesarnya BUMN berperan menghasilkan barang dan/atau jasa yang diperlukan bagi seluruh masyarakat, serta BUMN juga sebagai pelopor atau perintis dalam sector-sektor usaha yang belum diminati oleh swasta dan juga sebagai pelaksana pelayanan public, penyeimbang kekuatan-kekuatan swasta besar, membantu mengembangan UMKM, serta yang paling penting juga sebagai sumber penerima Negara dimana paling signifikan yaitu dalam berbagai jenis pajak, deviden dan hasil privatisasi (Ansari, 2017).

Badan Usaha Miliki Negara (BUMN) yang ada pada saat ini di Indonesia pada awalnya merupakan perusahaan-perusahaan belanda dan kemudian dinasionalisasi, sehingga dengan adanya nasionalisasai perusahaan belanda yang ada di Indonesia kemudian diambil alih oleh pemerintah yang mengakibatkan perusahaan BUMN memiliki fasilitas dan keistimewaan yang lebih dibandingkan dengan perusahaan swasta (Arif \& Ukasa, 2010). Privatisai menurut UU no 19 tahun 2003 tentang BUMN pengertian privatisasi dijelaskan pada pasal 1 poin 12 yiatu; 
"Privatisasi adalah penjualan saham persero, baik sebagian maupun seluruhnya, kepada pihak lain dalam rangka meningkatkan kinerja dan nilai perusahaan, memperbesar manfaat bagi Negara dan masyarakat, serta memperluas kepemilikan saham oleh masayrakat"

Pada intinya privatisasi tersebut hanya terkait dengan wacana untuk memperluas kepemilikan saham masyarakat, walaupun secara tegas UU No 19 tahun 2003 menegaskan bahwa kepemilikan saham mayoritas BUMN 51\% dimiliki oleh Negara. Dengan adanya saham mayoritas tersebut menjadikan BUMN kurang mandiri sehingga kurang mampu bersaing dengan penrsaingan bebas, privatisasi disalah artikan yaitu diartikan sebagai perusahaan penguasa. Hal itu mengakibatkan perusahaan BUMN banyak memonopoli usaha yang dijalankannya sehingga perusahaan swasta sulit masuk kedalamnya. Padahal privatisasi itu harusnya ditujukan pada bidang-bidang usaha yang dianggap menyangkut hajat hidup orang banyak, seperti perusahaan listrik, minyak dan gas bumi, sebagaimana diamanatkan dalam pasal 33 UUD 1945, yang seharusnya dikuasai oleh Negara (Yusroni, Nanang, 2007).

Selaian itu adanya pengusaan barang atau jasa tersebut kurang sejalan degan adanya UU No 5 tahun 1999 tentang larangan praktik monopoli dan persaingan usaha tidak sehat. UU No 5 tahun 1999 ini dianggap memberikan kesempatan yang sama kepada seluruh rakyat Indonesia dalam mengembangkan potensi ekonominya, sehingga praktik monopoli dan persaingan usaha tidak sehat merupakan praktikpraktik bisnis yang harus dihindari karena dampak yang ditimbulkan cukup besar yaitu ketidak efisienan pasar, distorasi pasar, yang kemudian dapat mengakibatkan ketidak adilan baik bagi konsumen maupun produsen (Tarigan, 2016). Pelaku usaha baik BUMN maupun swasta dalam menjalankan kegiatan usahannya harus berasaskan demokrasi ekonomi dengan memperhatikan keseimbangan antara pelaku usaha dan kepentingan umum serta harus melaksanakan tujuan dari UU No 5 tahun 1999 yaitu menerapkan pasar yang kompetitif sekaligus menghindari kesepakatan dan konspirasi yang cenderung mengurangi atau menghilangkan persaingan
(Malaka, 2014). Peranan dunia usaha yang didominasi oleh perusahaan besar baik BUMN maupun swasta sering terjadi pada dikuasainnya produk atau jasa tertentu sehingga menjurus pada terjadinya praktik monopoli, dimana praktik monopoli tersebut bersifat mengganggu perkembangan dunia usaha yang kadangkala justru dilindungi oleh pemrintah melalui kebijkan-kebijakan yang dikeluarkannya (Anggraini, 2010).

Perlindungan yang diberikan pemerintah tersebut bertujuan dalam rangka memenuhi pasal 33 UUD 1945, hal itu tertuang dalam pasal 51 Undang-undang no 5 tahun 1999 tentang praktik monopoli dan persaingan usaha tidak sehat, yang menyatakan bahwa;

"Monopoli dan atau pemusatan kegiatan yang berkaitan dengan produksi dan atau pemasaran barang dan atau jasa yang menguasai hajat hidup orang banyak serta cabang cabang produksi yang penting bagi negara diatur dengan undang undang dan diselenggarakan oleh Badan Usaha Milik Negara dan atau badan atau lembaga yang dibentuk atau ditenjuk oleh pemerintah"

Terkait dengan adanya pengecualian tersebut, terhadap monopoli dan/atau pemusatan kegiatan oleh Badan Usaha Milik Negara (BUMN) Komisi Pengawasan Persaingan Usaha (KPPU) menilai bahwa sebagian besar BUMN merasa bebas dari hukum persaingan usaha, para pelaku BUMN cenderung lebih leluasa berlindung dibelakang pasal 51, karena mereka memposisikan diri sebagai bagian Negara atau pemerintah (Toersian \& Haryani, 2012). Padahal jika ditinjau kembali posisi atau kedudukan BUMN sama dengan perusahaan perseroaan, yang membedakan hanya kepemilikan saham mayoritas saja. Hal itu tentunya menjadikan kekhawatiran yang dapat menimbulkan penyalah gunaan posisi BUMN. Yang kemudian KPPU mulai mengeluarkan suatu pedoman mengenai pemahaman isi maksut dari pasal 51 tersebut. KPPU menafsirkan maksut dari pasal 51 menjadi beberapa unsur, yaitu:

1. Monopoli dan/atau pemusatan kegiatan

2. Produksi dan/atau pemasaran barang dan/atau jasa yang menguasai hajat hidup orang banyak

3. Cabang-cabang produksi yang penting bagi Negara 
4. Diatur dengan undang-undang

5. Diselenggarakan oleh Badan Usaha Milik Negara dan atau badan atau lembaga yang dibentuk yang ditunjuk oleh pemerintah

Namun pengertian maksut dalam pasal 51 juga masih dirasa belum jelas, mengenai hal-hal apa saja yang dikecualikan dan hal-al apa yang menjadi maksut dari hajat hidup orang banyak serta cabang-cabang produksi apa yang penting bagi Negara. KPPU hanya menjelaskan yang termasuk dalam barang atau jasa yang menguasai hajat hidup orang banyak harus memiliki fungsi alokasi, distribusi dan stabilisasi. Sedangkan maksut dari cabang-cabang yang penting bagi Negara harus memiliki sifat strategis dan finansial (Anggraini, 2010).

Selain dari penafsiran oleh KPPU, terkait dengan penafsiran isi pasal 51 Mahkamah Konstitusi juga menafsirkannya kedalam suatu putusan MK. Penafsiran tersebut ada akibat dari adanya pengujian Undang-undang terkait dengan pasal 33 UUD 1945 yaitu pengujian Undang-undang No 20 tahun 2002 tentang ketenagalistrikan. Dimana MK menafsirkan maksut pasal 51 tersebut berpedoman pada pasal 33 UUD 1945 yang terdapat kalimat dikuasai oleh "Negara" dan "menyangkut hajat hidup orang banyak". Yang dimaksut dikuasai Negara yaitu bukanlah secara sepenuhnya Negara memonopoli tetapi masih memperbolehkannya pihak swasta untuk masuk kedalamnya asalkan pemerintah masih memiliki peran aktif didalamnya. Selain itu dalam putusannya, MK juga berpendapat bahwa cabang produksi yang pada suatu waktu penting bagi Negara dan menguasai hajat hidup orang banyak, pada waktu yang lain dapat berubah menjadi tidak penting bagi Negara atau tidak lagi menguasai hajat hidup orang banyak.

Dengan adanya dua penafsiran tersebut kemudian menjadi sebuah problematika mengenai kepastian hukum dan fungsi aturan bagi kesejahteraan sosail tersebut. Karena jika ditinjau dari dua penafsiran tersebut masih memiliki arti yang berbeda-beda, sehingga peneliti menganggap perlu dilakukan kajian ulang atau regulasi yang baru untuk memperjelas maksut dari isi pasal tersebut. Sehingga dalam praktiknya tidak terjadi salah penafsiran. Selain itu dari penjelasan yang sudah dijabarkan tersebut, saya sebagai peneliti tertarik entuk melakukan penelitian terkait dengan "Analisis Yuridis Kewenangan BUMN Untuk Melakukan Monopoli Dan Atau Pemusatan Kegiatan Dalam Perspektif Kepastian Hukum Dan Kesejahteraan Sosial”.

\section{Rumusan Masalah}

Dengan adanya penjelasan mengenai latar belakang tersebut maka penulis mengambil rumusan masalah tentang

1. Kegiatan apa saja yang menjadi kewenangan BUMN untuk melakukan monopoli dan atau pemusatan kegiatan dalam perspektif Mahkamah Konstitusi?

2. Kegiatan apa saja yang menjadi kewenangan BUMN untuk melakukan monopoli dan atau pemusatan kegiatan dalam perspektif KPPU?

3. Bagaimana pengaturan kewenangan BUMN dalam melakukan monopoli dan/atau pemusatan kegiatan dalam perspektif kepastian hukum dan kesejahteraan sosial?

\section{Jenis Penelitian}

\section{METODHOLOGY}

Dalam penelitian ini, peneliti menggunakan jenis penelitian Hukum Normatif. Yang dimaksud dengan penelitian hukum normatif yaitu suatu proses dimana proses tersebut bertujuan untuk menemukan sutu aturan hukum, prinsip-prinsip hukum, maupun doktrindoktrin hukum guna menjawab isu hukum yang sedang dihadapi (Peter Mahmud Marzuki, 2009). Alasan peneliti menggunakan jenis penelitian normatif karena peneliti berharap dapat memberikan atau menghasilkan argumentasi, teori atau konsep baru sebagai deskripsi dari penyelesaian isu hukum yang telah diambil.

\section{Pendekatan Penelitian}

Pendekatan penelitian hukum harus dilakukan dalam melakukan penelitian, hal itu bertujuan untuk membantu peneliti dalam mendapatkan informasi dari berbagai aspek mengenai isu hukum yang sedang dicari jawabannya. Oleh karena itu maka penulis dalam hal ini menggunakan 3 pendekatan, yaitu:

a. pendekatan Undang-undang, yaitu dengan menelaah semua Undang-undang dan regulasi yang bersangkutan dengan isu hukum yang 
sedang ditangani atau pendekatan ini juga bisa disebut dengan pendekatan menggunakan legislasi dan regulasi (Peter Mahmud Marzuki, 2009).

b. Pendektan konseptuan, pendekatan ini akan mempelajari dari segi undang-undang, doktrindoktrin didalam ilmu hukum serta meliha konsepkonsep Good Corporate Govermance yang terdapat dari berbagai literatur sehingga penelita akan menemukan ide-ide yang melahirkan pengertian-pengertian-pengertian hukum, konsep-konsep hukum, dan asas-asas hukum yang relevan dengan isu yang dihadapi (Peter Mahmud Marzuki, 2009).

c. Pendekatan filosofis atau filsafat, pendekatan ini bukan bertujuan untuk menjawab dari permasalahan yang ada, tetapi lebih menuju ke menemukan permasalahan Karena sifat filsafat yang menyeluruh, mendasar dan spekulatif. Pendekatan filsafat ini akan lebih membentuk Fundamental Research, yaitu dalam penelitioan ini akan lebih memperoleh pemahaman yang lebih terhadap implikasi sosial dan dampak dari penerapan suatu undang-undang terhadap masyarakat atau suatu kelompok masyarakat yang didalam penelitian berkaitan dengan sejarah, filsafat, ilmu bahasa, ekonomi dan juga implikasi sosial serta potik terhadap pemberlakuan suatu aturan hukum yang ada.

\section{Sumber Bahan Hukum}

Dalam penelitian ini peniliti menggunakan 3 jenis sumber bahan hukum, yaitu:

a. Bahan Hukum Primer

Bahan hukum primer merupakan bahan hukum yang bersifat autoritatif artinya mempunyai otoritas, dimana bahan hukum ini terdiri dari perundang-undangan, catatan-catatan resmi atau risalah dalam membuat perundang-undangan dan putusan-putusan hakim jika dibutuhkan (Peter Mahmud Marzuki, 2009).

1) Undang Undang Dasar 1945.

2) Undang Nomor 5 tahun 1999 tentang larangan praktik monopoli dan persaingan usaha tidak sehat.
3) Undang-undang Nomor 19 tahun 2003 tentang Badan Usaha Miliki Negara (BUMN).

4) Peraturan Komisi Pengawas Persaingan Usaha Nomor 3 tahun 2010 tentang pedoman pelaksanaan ketentuan pasal 51 Undangundang Nomor 5 tahun 1999 tentang larangan praktik monopoli dan persaingan usaha tidak sehat.

5) Peraturan Komisi Pengawas Persaingan Usaha Nomor 11 tahun 2011 tentang pedoman pasal 17 (praktik monopoli) Undang-undang Nomor 5 tahun 1999 tentang larangan praktik monopoli dan persaingan usaha tidak sehat.

b. Bahan Hukum Sekunder

Bahan hukum sekunder yaitu berupa semua publikasi tentang hukum yang bukan merupakan dokumendokumen resmi, biasanya berupa buku-buku hukum atau referensi-refensi, jurnal-jurnal, karya tulis ilmiah, internet bahkan juga surat media masa yang keseluruhannya terkait dengan isu hukum yang ada (Peter Mahmud Marzuki, 2009).

c. Bahan Hukum Tersier

Bahan hukum tersier juga merupakan bahan hukum yang juga harus dapat menjelaskan bahan hukum primer maupun bahan hukum sekunder. Bahan hukum ini dibutuhkan untuk menunjang bahan hukum lainnya.

\section{Metode Pengumpulan dan Pengolahan Bahan Hukum}

Metode pengumpulan data pada penelitian ini dengan melakukan studi pustaka terhadap bahan-bahan hukum, baik bahan hukum primer, bahan sekunder mapun bahan hukum tersier. Studi kepustakaan dilakukan dengan cara menelaah, membaca, mencatat segala hal-hal yang berkaitan dengan isu hukum yang sedang dibahas selain itu juga membuat ulasan bahanbahan pustaka yang terkait. Metode pengumpulan bahan hukum ini juga dapat dilakukan dengan cara documenter, yaitu dikumpulkannya referensi dari berbagai sumber baik jurnal, makalah, penelitian, buku-buku, Koran , majalah, internet dll terkait segala hal yang berkaitan dengan isu hukum yang diangkat. Peneliti dalam hal ini menggunakan pendekatan perundang-undangan, hal pertama yang harus perlu dilakukan pula yaitu mencari dan mengumpulkan 
peraturan perundang-undangan mengenai atau yang berkaitan dengan isu hukum yang sedang di bahas (Peter Mahmud Marzuki, 2009). Selain itu wawancara juga dapat dilakukan, hal ini bertujuan untuk menunjang tknik dokumenter dan memperoleh bahan hukum untuk menjawab isu hukum yang terjadi.

Semua bahan hukum yang telah dikumpulkan tersebut kemudian diolah, dalam penlitian ini digunakan metode pengolahan dengan cara editing, yaitu dengan cara memeriksa kembali bahan-bahan hukum yang diperoleh baik dari segi kelengkapannya, kesesuaian, kejelasan, serta relevansinya dengan bahan hukum yang lain (Saifullah, 2004).

\section{Metode Analisis Bahan Hukum}

Peneliti dalam menganalisa bahan hukum yang ada dengan cara mengklasifikasikan bahan-bahan hukum yang ada agar mudah dianalisis dan dikonstruksikan. Dalam hal ini karena jenis penelitian berupa penelitian normatif maka maka sistem analisisnya dengan cara diskriptif kualitatif yang merupakan analisa data-data yang tidak bisa dihitung. Kemudian bahan hukum yang sudah diperoleh kemudian dikelompokkan, diperiksa dan kemudian dilakukan pembahasan. Setelah itu bahan hukum kemudian akan di interpretasikan dengan metode interprertasi sistematis, gramatikal dan teleologis (Asshiddiqie, 1996).

\section{HASIL PENELITIAN DAN PEMBAHASAN}

Kewenangan BUMN untuk melakukan monopoli dan atau pemusatan kegiatan dalam perspektif Mahkamah Konstitusi

Adanya kewenangan untuk memonopoli dan pemusatan kegiatan oleh BUMN sesuai degan isi pasal 51 Undang-undang No 5 tahun 1999 tentang larangan praktik monopoli dan persaigan usaha tidak sehat, yang kewenangan BUMN secara tidak langsung tersirat dalam suatu putusan MK terkait dengan putusan pengujian Undang-undang Nomor 20 tahun 2002 tentang ketenagalistrikan. Isi dalam putusan menurut peneliti diaggap telah mencakup maksut adanya pasal 51 yang pada intinya berkaitan dengan "hajat hidup orang banyak" yang lebih tertuju pada pasal 33 UUD 1945 didalamnya terdapat pula maksut "menguasai negara". Undang-undang No 20 tahun 2002 dianggap telah bertentangan dengan pasal 33 Undang Undang
Dasar 1945. Padahal dalam hakikatnya adanya pasal 51 terbentuk berdasar pada pasal 33 tersebut, serta adanya UU 20 tahun 2002 tentang ketenagalistrikan ada keterikatan dengan pasal 51 UU No 5 tahun 1999 tentang pelaksanaan BUMN untuk melakukan monopoli dan pemusatan kegiatan terhadap tenaga listrik. UU No 20 tahun 2002 dianggap telah membuka peluang untuk pihak swasta masuk ikut serta kedalam sektor ketenagalistrikan. Yang kemudian ada beberapa organisasi kemasyarakat yang mengajukan permohonan pengujian terhadap Undang-undang No 29 tahun 2002 tersebut. Adapun diantara beberapa pasal yang diajukan pemohon dan kemudian di tanggapi oleh pemerintah yaitu dapat di sampaikan dalam table berikut (Magnar, Junaenah, \& Taufik, 2010):

Tabel I

Persandingan Argumentasi Pemohon dan Pemerintah

Terkait Putusan Pengujian UU No 20/2002

\begin{tabular}{|c|c|c|c|}
\hline $\mathbf{N}$ & $\begin{array}{c}\text { Pokok } \\
\text { Penguj } \\
\text { ian }\end{array}$ & Pemohon & rintah \\
\hline 1 & $\begin{array}{c}\text { Menim } \\
\text { bang c } \\
\text { UU No } \\
20 \\
\text { tahun } \\
2002 \\
\text { bertent } \\
\text { angan } \\
\text { dengan } \\
\text { pasal } \\
33 \\
\text { UUD } \\
1945\end{array}$ & $\begin{array}{l}\text { Kedudukan } \\
\text { Negara dalam } \\
\text { usaha diwakili } \\
\text { oleh BUMN } \\
\text { menjadikan } \\
\text { BUMN } \\
\text { memiliki } \\
\text { kedudukan } \\
\text { yang sama } \\
\text { dengan pihak } \\
\text { swasta dalam } \\
\text { usaha } \\
\text { penyediaan } \\
\text { tenaga listrik } \\
\text { untuk } \\
\text { kepentingan } \\
\text { umum. Maka } \\
\text { dari itu Negara } \\
\text { tidak lagi } \\
\text { menguasai } \\
\text { usaha } \\
\text { penyediaan } \\
\text { tenaga listrik } \\
\text { dan tidak ada } \\
\text { jaminan yang }\end{array}$ & $\begin{array}{l}\text { Negara tetap } \\
\text { bertanggung } \\
\text { jawab melalui } \\
\text { pengaturan atau } \\
\text { hak regulasi, } \\
\text { menguasai hajat } \\
\text { hidup orang } \\
\text { banyak tidak } \\
\text { berarti } \\
\text { memiliki, } \\
\text { bahkan } \\
\text { memonopoli } \\
\text { baik secara } \\
\text { langsung } \\
\text { maupun tidak } \\
\text { langsung } \\
\text { melalui } \\
\text { pengaturan } \\
\text { kegiatan usaha. }\end{array}$ \\
\hline
\end{tabular}




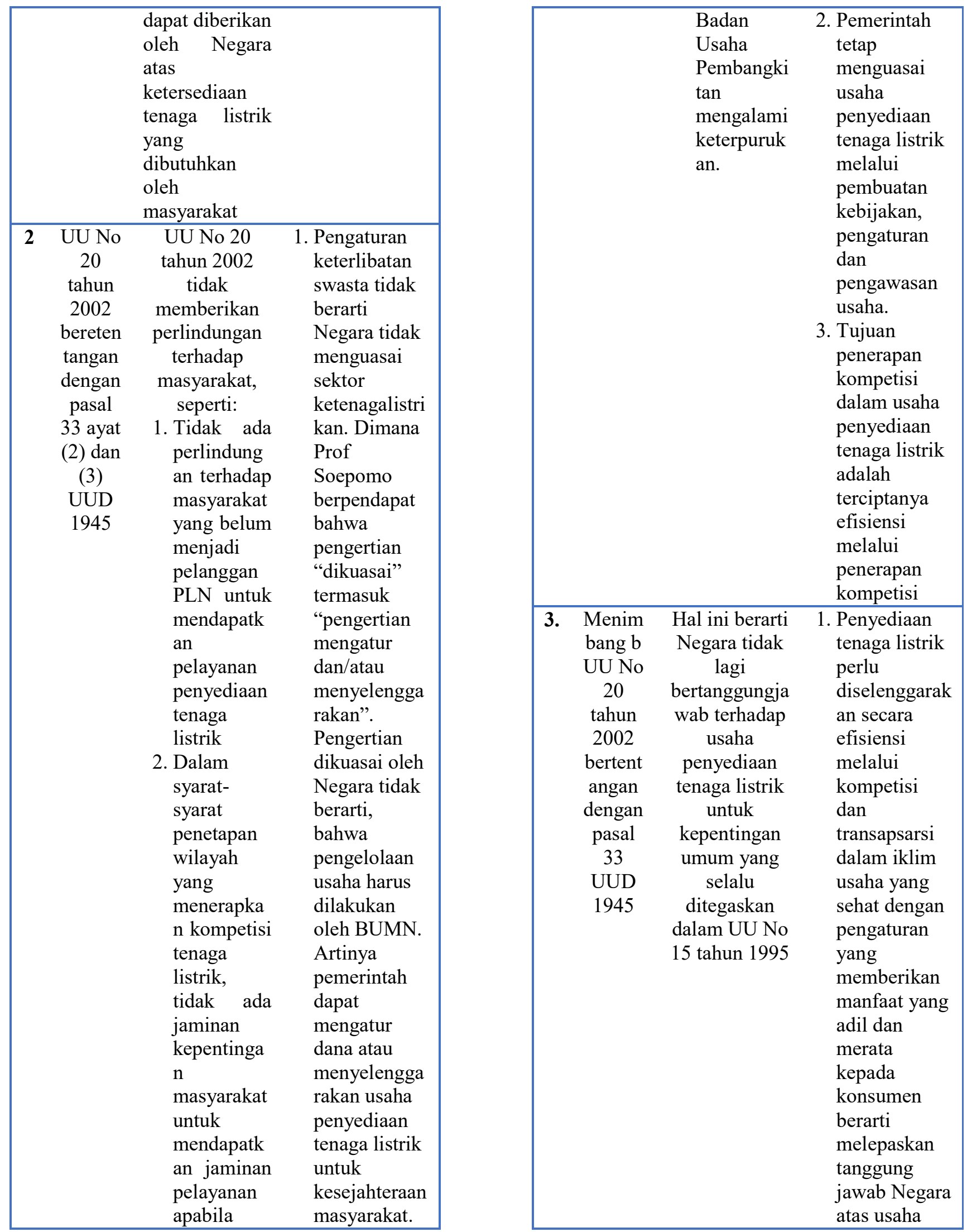




\begin{tabular}{|c|c|c|}
\hline & & $\begin{array}{l}\text { penyediaan } \\
\text { tenaga listrik } \\
\text { harus ditolak } \\
\text { karena } \\
\text { penerapan } \\
\text { kompetis } \\
\text { tidak berarti } \\
\text { melepaskan } \\
\text { tanggungjaw } \\
\text { ab Negara } \\
\text { untuk } \\
\text { menyediakan } \\
\text { tenaga listrik. } \\
\text { 2. Pemeritah } \\
\text { melakukan } \\
\text { pengawasan } \\
\text { terhadap } \\
\text { penerpana } \\
\text { kompetisi } \\
\text { dan wajib } \\
\text { menjamin } \\
\text { kecukupan } \\
\text { pasokan } \\
\text { tenaga listrik } \\
\text { diwilayah } \\
\text { kompetisi. }\end{array}$ \\
\hline $\begin{array}{c}\text { 4. Pasal } \\
15 \text { ayat } \\
(2)\end{array}$ & $\begin{array}{c}\text { Badan } \\
\text { pengawas } \\
\text { pasar tenaga } \\
\text { listrik yang } \\
\text { dimaksut } \\
\text { Undang- } \\
\text { undang } \\
\text { Nomoer } 20 \\
\text { tahun } 2002 \\
\text { mempunyai } \\
\text { fungsi yang } \\
\text { sama, dan akan } \\
\text { berbenturan } \\
\text { dengan Komisi } \\
\text { Pengawas } \\
\text { Persaingan } \\
\text { Usaha (KPPU) } \\
\text { yang } \\
\text { ditetapkan } \\
\text { dalam } \\
\text { Undnag- } \\
\text { undang No 5 } \\
\text { tahun 1999. } \\
\text { Maka dari itu } \\
\text { akan timbul } \\
\text { ketidak pastian }\end{array}$ & 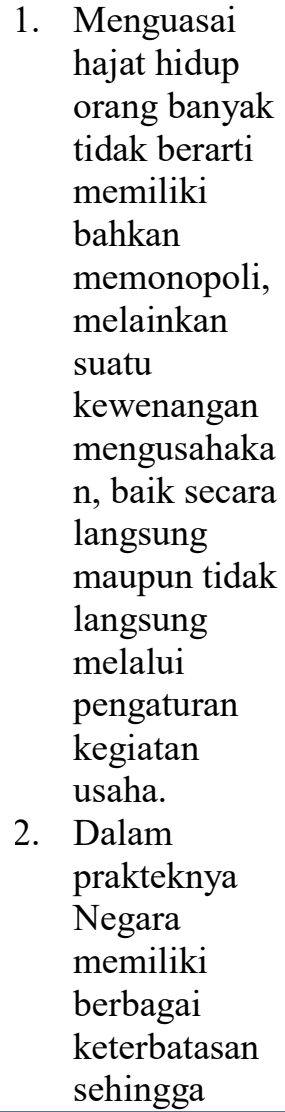 \\
\hline
\end{tabular}

\section{hukum dalam pengawasan kompetisi yang akan diterapkan.}

tidak mampu mengusahaka $\mathrm{n}$ sendiri oleh Negara justru menimbulkan kerugian bagi masyarakat, karena pelaksanaann ya tidak efisien, transparan dan professional.

3. Bahwa karena keterbatasann ya, Negara perlu dibentuk dengan memberikan kesempatan kepada masyarakat berpartisipasi dalam cabangcabang produksi yang penting bagi masyarakat melalui program swatanisasi.

4. Dari adanya pengaturan untuk penerapan kompetisi, dan pembentukan lembaga pemerintah yang melakukan pengawasan kompetisi membuktikan , bahwa Negara tetap 


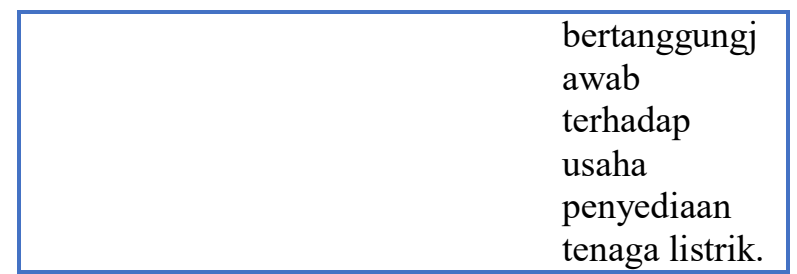

Sumber: Putusan Mahkamah Konstitusi PUU Nomor: 001/PUU-(2002)

Dari adanya permohoan dan argument tersebut maka, putusan MK dapat disimpulkan sebagai berikut:

1. Walupun saham BUMN bersifat mayoritas atau mutlak, sepanjang pemerintah masih memegang saham mayoritas relatife tersebut secara hukum tetap memegang kedudukan menentukan dalam pengambil keputusan di BUMN. Dalam hal ini maka harus dipahami bahwa Negara tetap sebagai pihak yang menentukan dalam proses pengambilan keputusan atas penentuan kebijakan dalam BUMN yang dimaksut, dimana digambarkan penguasaan Negara mencakup pengaturan, pengurusan, pengelolaan dan pengawasan. Selain itu perlu dipahami juga dalam hal ini maka pemerintah serta merta tidak sepenuhnya memiliki dan memonopoli dalam kegiatan usaha. Dapat disimpulkan bahwa pemerintah masih membuka peluang untuk swasta masuk dalam melakukan konstribusi membantu pemerintah dalam memenuhi hajat hidup orang banyak.

2. Karena tenaga listrik masih dianggap sebagai cabang produksi yang penting bagi Negara dan menguasai hajat hidup orang banyak, sehingga menurut pasal 33 harus tetap dikuasai oleh Negara, dalam arti luas harus dikelola oleh Negara melalui perusahaan Negara yang harus didanai oleh pemerintah, dengan melakukan kemitraan bersama swasta . Dapat disimpulkn bahwa hanya BUMN yang boleh mengelola, sedangkan perusahaan swasta atau asing dapat ikut serta apabila diajak kerjasama oleh BUMN. Selain itu perusahaa yang dimaksut yaitu PLN, ketika merasa tidak mampu melakukan tugasnya boleh dilakukan pembagian tugas dengan BUMN lainnya atau BUMD.

Kemudian berikut adalah penafsiran MK atas maksut pasal 33 UUD 1945 dalam putusan PUU No 20 tahun 2002 tentang ketetnagalistrikan:

\section{1) Prinsip dikuasai Negara}

Dalam UUD 1945 mengamanatkan bahwa sumberdaya alam (bumi,air, dan ruang angkasa) dikuasai oleh Negara dan harus dipergunakan sebesarbesarnya kemakmuran rakyat. Namun ada pendapat dari Mohammad Hatta yang menyatakan bahwa pengertian dikuasai oleh Negara tidak berarti Negara sendiri menjadi pengusaha, usahawan atau ordernemer, namun lebih jelasnya dapat dikatakan bahwa kekuasaan neagara terdapat pada membuat peraturan guna memperlancar jalan ekonomi, peraturan yang melarang pula penghisapan orang yang lemah oleh orang yang bermodal (Hatta, 1977). Namun secara logis dijelaskan bahwa sumber daya alam tidak boleh dikuasai secara mutlak oleh perorangan, badan hukum, atau kelompok orang tertentu melainkan harus oleh Negara yang merupakan organisasi kekuasaan seluruh rakyat yang berdaulat. Namun dalam hal ini perlu dijelaskan lebih lanjut mengenai sumber daya alam mana yang tidak boleh dikuasai oleh perorangan. Yang dimana hal tersebut tidak dijelaskan oleh MK. PUU pasal 20 tahun 2002 tersebut hanya menjelaskan mengenai penegasan berupa bentuk hak hak pemanfaatan (penggunana) saja. Padahal pada implementasinya terdapat hak milik yang dalam hal ini tidak dijelaskan pada PUU MK tersebut. Lebih jelasnya bahwa rakyat secara kolekif dikonstruksikan oleh UUD 1945 memberikan mandate kepada pemerintah untuk melakukan kebijakan (beleid) dan tindakan pengursan (bestuursdaad), pengaturan (regelendaad), pengelolaan (beheersdaad) dan pengawasn (toezichthoundensdaad) utnuk tujuan sebesar-besarnya kemakmuran rakyat. Keterkaitan pihak swasta tetap dimungkinkan asalkan masih terdapat 5 peran pemerintah tersebut didalamnya.$^{2}$ Jadi secara konstitusional penanggung jawab pengelolaan sumber daya alam adalah pemerintah namun sejalan harus sejalan dengan prinsip demokrasi dimana pemerintah 
membuka luas keterlibatan masyarakat, keterlibatan masyarakat tersebut dapat timbul melalui instrument "izin" dan "konsesi" atau "lisensi".

2) Cabang-cabang produksi yang penting bagi Negara dan menguasai hajat hidup orang banyak.

Mengenai hal ini menurut ketentuan pasal 33 ayat (2) dikuasai oleh Negara, tergantung pada kondisi dinamika perkembangan kondisi kekayaan masingmasing cabang produski yang harus dikuasai Negara jika:

(i) Cabang-cabang produksi itu penting bagi Negara dan menguasai hajat hidup orang banyak

(ii) Penting bagi Negara tetapi tidak menguasai hajat hidup orang banyak

(iii) Tidak penting bagi Negara tetapi menguasai hajat hidup orang banyak

Ketiga hal tersebut harus dikuasai oleh Negara dan dipergunakan sebesar-besarnya untuk kemakmuran rakyat. Namun kembali kepada pemerintah dengan lembaga perwakilan rakyat untuk menilai apa dan kapan suatu cabang produksi tersebut diniali penting bagi Negara dan atau menguasai hajat hidup orang banyak. Cabang produksi yang pada saat ini dinilai penting bagi Negara dan menguasai hajat hidup orang banyak pada lain waktu dapat berubah menajadi tidak penting dan tidak lagi menguasai hajat hidup orang banyak.

Dari adanya penjelasan tersebut terkait dengan wewenag BUMN untuk melakukan monopoli dan pemusatan keiatan, peneliti menganggap bahwa walaupun terdapat pengecualian oleh pasal 51 UU No 5 tahun 1999 tersebut, tetapi tidak memungkikan untuk pihak swasta masuk kedalamnya asalkan masih terdapat peran pemerintah didalamnya. Dapat disimpulkan bahwa BUMN hanya sebagai pelaksana dari ketentuan-ketentuan yang diberikan oleh pemerintah. Namuan jika ditinjau kembai mengenai putusan MK tersebut, belum dijelaskan secara mendetail mengenai hal-hal apa saja yang penting bagi Negara dan menguasai hajat hidup orang banyak. Maka perlau diberlakukaannya suatu prodak hukum mengenai apa yang sekarang penting dan tidak penting bagi Negara dan menguasai hajat hidup orang banyak sehingga tidak ada multitafsir.
Kewenangan BUMN untuk melakukan monopoli dan atau pemusatan kegiatan dalam perspektif KPPU

Sebelum membahas mengenai kewenangan BUMN dalam melakukan monopoli dan pemusatan kegiatan yang tertuang di pasal 51 Undang-undang no 5 tahun 1999 tentang larangan praktik monopoli dan persaingan usaha tidak sehat yang kemudian ditinjau dari pandangan KPPU, maka perlu diketahui kemali isi dari pasal 51 tersebut, yaitu;

"Monopoli dan atau pemusatan kegiatan yang berkaitan dengan produksi dan atau pemasaran barang dan atau jasa yang menguasai hajat hidup orang banyak serta cabang-cabang produksi yang penting bagi Negara diatur dengan Undang-undang dan diselenggarakan oleh Badan Usaha Milik Negara dan atau badan atau lembaga yang dibentuk atau ditunjuk oleh pemerintah"

Dari penjelasan isi pasal tersebut dapat diuraikan maksut dari pasal tersebut menurut KPPU yaitu;

1. Monopoli dan atau pemusatan kegiatan

Yang dimaksut monopoli dalam pasal 1 angka 1 monopoli dapat diartikan sebagai (KPPU, n.d.):

"penguasaan atas produksi dan atau pemasaran barang dan atau jasa tertentu oleh 1 (satu) pelaku usaha atau 1 (satu) kelompok pelaku usaha"

Dari penjelasan pasal tersebut dapat dikatakan bahwa monopoli itu merupakan kegiatan penguasaan atas suatu barang dan jasa dimana dalam melakukan penguasaan tersebut tanpa harus melakukan persaingan atau bahkan tanpa melakukan praktik monopoli dan persaingan usaha yang tidak sehat. Sedangkan maksut pemusatan kegiatan dapat diartika sebagai suatu pnguasaan atas suatu kondisi dimana dalm penguasaan tersebut, penguasa berhak untuk menentukan seluruh kegiatan didalamnya serta menentukan harga tanpa melakukan praktik monopoli dan persaingan usaha tidak sehat. Jika dianalisa kembali maka kegiatan monopoli dan pemusatan kegiatan dalam pasal ini tidak dilarang sehingga tidak melanggar aturan Undang-undang no 5 tahun 1999 mengenai praktik monopoli, dimana sesuai ketentuan pasal 1 angka 2 dijelaskan mengenai pengertian praktik monopoli itu sendiri yaitu: 
"pemusatan kekuatan ekonomi oleh 1 (satu) atau lebih pelaku usaha yang mengakibatkan dikuasainya produksi atau pemasaran atas barang dan atau jasa tertentu sehingga menimbulkan persaingan usaha tidak sehat dan dapat merugikan kepentingan umum"

Dilihat dari pengertian dalam Undang-undang Nomor 5 tahun 1999 antara pengertian monopoli dan praktik monopoli dapat disimpulkan bahwa kegiatan monopoli tidak sepenuhnya dilarang asalkan kegiatan monopoli tidak menimbulkan praktik monopoli yaitu dengan memanfaatnkan hak monopoli yang dimilikinnya untuk melakukan tindakan yang berindikasi menjadi persaingan tidak sehat dan merugikan orang lain. Hal itu dijelaskan pada pasal 17 Undang-undang Nomor 5 tahun 1999 yang mengatakan bahwa (KPPU, n.d.):

1. Pelaku usaha dilarang melakukan penguasaan atas produksi dan atau pemasaran barang dan atau jasa yang dapat mengakibatkan terjadinya praktik monopoli dan persaingan usaha tidak sehat.

2. Pelaku usaha patut diduga atau dianggap melakukan penguasaan atas produksi dan atau pemsaran barang dan atau jasa sebagaimana dimaksut dalam ayat (1) apabila:

a. Barang dan atau jasa yang bersangkutan belum ada subtitusinya atau,

b. Mengakibatkan pelaku usaha lain tidak dapat masuk kedalam persaingan usaha baran dan atau jasa yang sama, atau

c. Satu pelaku usaha atau satu kelompok pelaku usha menguasai lebih dari $50 \%$ (lima puluh persen) pangsa pasar satu jenis barang atau jasa tertentu.

Monopoli memang pada dasarnya tidak dilarang, tetapi bisa dilarang apabila monopoli menimbulkan praktik monopoli, dimana praktik monopoli tersebut dapat menimbulkan persaingan tidak sehat. Monopoli dapat terjadi secara ilmiah, ada beberapa argument yang dapat dikemukakan sehubungan dengan proses terjadinya monopoli secara alamiah. Hal-hal tersebut antara lain (Yani \& Widjaja, 1999):

a. Monopoli terjadi sebagai akibat dari suatu "superior skill", yang salah satunya dapat terwujud dari pemberian hak paten secara eksklusif oleh Negara, berdasarkan pada peraturan perundang-undangan yang berlaku kepada pelaku tertentu atas hasil riset dan pengembangan atas teknologi tertentu. Terdapat juga istilah mengenai "trade secret" yang meskipun tidak eksklusifitas "pengakuan" oleh Negara, namun dengan teknologi rahasiannya mampu membuat produk superior.

b. Monopoli terjadi karena adanya pemberian Negara. Di Indonesia hal ini hal ini dapat dilihat pada pelaksanaan ketentuan pasal 33 ayat (2) dan pasal 33 ayat (3) Undang Undang Dasar 1945 yang dikutip kembali dalam pasal 51 Undang-undang Nomor 5 tahun 1999.

c. Monopoli merupakan suatu "historical accident", karena monopoli terjadi dengan tidak sengaja, dan berlangsung karena proses alamiah, yang ditentukan oleh berbagai faktorterkait dimana monopoli tersebut terjadi. Dalam hal ini penilaian mengenai pasar bersangkutan yang memungkinkan terjadinya monopoli menjadi sangat relevan.

Penjelasan mengenai terjadinya monopoli secara alamiah tersebut, mengakibatkan adanya pengecualian terhadap monopoli, yaitu sesuai dengan penjelasan pada Undang-undang Nomor 5 tahun 1999 tentang larangan praktik monopoli dan persaingan tidak sehat pasal 51. Pengecualian tersebut harus dimanfaatkan oleh para perusahaan untuk menjadikan perusahaan jadi lebih baik, walaupun secara tidak langsung tidak sepenuhnya monopoli dilarang. Tetapi indikasi terjadinya praktik monopoli masih mungkin terjadi, sehingga hal itu dapat mengakibatkan persaingan tidak sehat.

2. Produksi dan atau pemasaran barang dan atau jasa yang menguasai hajat hidup orang banyak Yang dimaksut produksi, pemasaran barang atau jasa yaitu segala bentuk produksi atas suatu barang yang serta jasa dimana barang dan jasa tersebut ada dan di butuhkan oleh seluruh masyarakat. Selain itu maksut dari kalimat produksi atau barang dan jasa yang menguasai hajat hidup orang banyak dapat ditinjau dari penafsiran sistematis, dimana yang dimaksut dengan penafsiran sistematis yaitu salah 
satu cara menafsirkan dari suatu rumusan norma hokum dengan cara menghubungkan dengan peraturan hokum atau rumusan yang lainnya dari satu Undang-undang (Mertokusumo, 2009). Yang kemudian maksut dari pasla tersebut ditafsirkan harus mencakup 3 hal (KPPU, n.d.):

1. Fungsi alokasi

Fungsi alokasi ini yaitu ditujukan pada suatu barang atau jasa yang berasal dari Sumber Daya Alam yang dikuasi oleh Negara dan untuk dimanfaatkan sebesar-besarnya untuk kemakmuran rakyat atau masyarakat. Misalnya yaitu air, hasil pertanian, tambang dll

2. Fungsi distribusi

Fungsi distribusi ini yaitu suatu barang atau jasa yang diarahkan demi memenuhi kebutuhan masyarakat secara pokok, tetapi yang pada saat tertentu dan terus menerus tidak dapat dipenuhi oleh pasar. Maka dalam fungsi distribusi ini dianggap hanya pemerintah yang mampu mendistribusikan barang dan jasa tersebut, pihak swasta tidak mampu untuk masuk keranah ekonomi yang dimaksut. Menurut peneliti jika ditinjau dari fungsi distribusi maka peneliti berpendapat dalam segala sektor ini swasta mampu melakukan pendistribusiannya tergantung bagimana regulasi pemerintah dalam megaturnya. Mislanya dalam pendistribusian beras, gula, minyak dll

3. Fungsi stabilasi

Fungsi ini berkaitan dengan barang atau jasa yang harus disediakan untuk kepentingan umum, seperti barang atau jasa dalam pertahanan kemanan, moneter dan fiskal yang mengharuskan pengaturan dan pengawasan bersifat fiskal. Jika dilihat dari fungsi stabilasi ini yaitu bisa mnegenai pencetakan uang, pebuatan senjata dan hal hal lain yang memungkinkan.

Selai itu jika ditafsirkan kembali antara maksut barang dan jasa yang menguasai hidup hajat orang banyak dapat ditinjau dari UUD 1945 pasal 33 ayat 3:

"Bumi dan air dan kekayaan alam yang terkandung didalamnya dikuasai oleh Negara dan dipergunakan untuk sebsar-besarnya kemakmuran rakyat"
Maka barang yang dimaksut yaitu barang yang berseumber dari alam. Namun jika ditinjau dari fungsi stabilisasi maka tidak hanya barang yang bersumber dari alam saja melainkan semua kegiatan yang dimana kegiatan tersebut harus diawasi oleh Negara dan diperuntukkan untuk kepentingan orang banyak. Mislanya saja yitu jasa yang dilakukan BUMN peruri dimana perusahaan ini berkerja dalam bidang jasa pencetakan uang yang notabane kegiatan produksi tersebut harus diawasi oleh Negara, selain itu terdapat juga pendistribusian tenaga listik, pendistribusian bahan bakar minyak dll.

\section{Cabang-cabang produksi yang penting bagi Negara}

Maksut dari cabang-cabang produksi yang penting bagi Negara peneliti menafsirkannya sebagi suatu wadah dimana wadah tersebut bertujuan untuk menjalankan kegiatan ekonomi dalam bidanag barang atau jasa yang dimaksut dalam Undang-undang dan diawasi atau dibawah wewenang Negara. Secara sistematis cabang-cabang produksi tersebut harus memiliki dua sifat:

1. Sifat yang strategis, maksutnya yaitu cabang cabang produksi yang dapat dikatakan memiliki kelayakan atau dapat dipercaya untuk melakukan pendistribusian barang atau jasa, baik layak secara tempat, manajemen usaha, SDM dan sebaginya. Selain itu cabang produski yang dimaksut harus secara langsung mampu melindungi kepentingan pertahanan Negara dan menjaga kemanan nasional.

2. Sifat yang financial, dimana peneliti menafsirkan maksut dari sifat financial yaitu kegiatan memproduksi barang dan jasa harus dapat memberikan respon atau kontribusi yang besar bagi perekonomian Negara. Secara singkat dapat dikatakan bahwa cabang produksi harus berkaitan erat mengkatkan pendapatan Negara untuk menjaga kestabilan moneter dan jaminan perpajakan, serta sektor jasa keunangan yang dapat dimanfaatkan untuk kepentingan umum.

\section{Yang diatur oleh Undang-undang}


Dalam hal ini diartikan bahwa harus diatur oleh undang-undang, berarti harus memenuhi syarat secara legal dari Negara dalam malakukan monopoli atau penguasaan atas suatu barang dan jasa yang menguasai hajat hidup orang banyak serta cabang-cabang produksi yang penting bagi Negara. Berarti dalam hal ini berarti kegiatan monopoli atau pemusatan kegiatan boleh dilakukan ketika sudah diatur terlebih dahulu dalam bentuk Undang-undang, atau bisa diartikan Peraturan Undang-undangan yang bukan di bawah peraturan perundang-undangan. Selain itu peraturan tersebut harus mencantumkan secara jelas tujuan dilakukannya monopoli dan pemusatan kegiatan, serta bagimana system pengendalian dan pengawasan Negara terhadap penyelenggaraan monopoli dan pemusatan kegiatan tersebut, sehingga tidak mengarah atau menimbulkan praktik monopoli dan persaingan usaha tidak sehat.

Penafsira tersebut berarti menunjukkan bahwa monopoli dan pemusatan kegiatan terhadap barang dan jasa yang berkaitan dengan hajat hiduo orang banyak dapat diselenggarakan oleh Badan Usaha Milik Negara dan/atau badan lembaga yang dibentuk atau ditunjuk oleh pemerintah. Sehingga penafsiran tersebut sudah sesuai dengan isi pasal 51 UU no 5 tahun 1999 tentang larangan parktik Monopoli dan persaingan usaha tidak sehat.

\section{Diselenggrakan oleh Badan Usaha Milik Negara dan atau badan atau lembaga yang dibentuk atau ditunjuk oleh pemerintah \\ a) Diselenggarakan Oleh Badan Uasha Milik Negara \\ Maksut dari diselenggarakan oleh Badan Usaha} Milik Negara berarti yang diamanatkan oleh Undangundnag untuk melakukan kegiatan monopoli dan pemusatan terhadap suatu barang dan jasa yang berkaitan dengan hajat hidup orang banyak yaitu Badan Usaha Milik Negara (BUMN). Dimana menurut pasal 1 angka 1 UU No 19 tahun 2003 yang dimaksut Badan Usaha Milik Negara yaitu:

"Badan usaha yang seluruh atau sebagian besar modalnya dimiliki oleh Negara melalui penyertaan secara langsung yang berasal dari kekayaan Negara yang dipisahkan"
Penyelenggaran monopoli dan pemusatan kegiatan yang diberikan kepada BUMN diharapkan juga mampu untuk mencapai tujuan dari didirikannya BUMN itu sendiri yaitu, didirikannya BUMN menurut Undangundang No 19 tahun 2003 pasal 2 ayat (1) yaitu (KPPU, n.d.):

1. memberikan sumbangan bagi perkembangan perekonomian nasional pada umumnya dan penerimaan negara pada khususnya, secara tidak langsung BUMN hadir untuk negeri dalam rangka meningkatkan perekonomian di Indonesia.

2. Mengejar keuntungan, maksutnya yaitu perusahaan BUMN selain untuk membantu perekonomian negara tetapi juga harus memperoleh keuntungan yang sebesar-besarnya untuk meningkatkan kualitas perusahaan agar mampu berkembang lebih baik dan tidak kalah bersaing dengan perusahaan lainnya.

3. Menyelenggarakan kemanfaatan umum berupa penyediaan barang dan/atau jasa yang bermutu tinggi dan memadai bagi pemenuhan hidup hajat orang banyak. Maksutnya BUMN hadir untuk negeri dengan menyediakan barang atau jasa yang berkualitas dan bermutu tinggi serta bermanfaat bagi seluruh warga masyarakat Indonesia.

4. menjadi perintis kegiatan-kegiatan usaha yang belum dapat dilaksanakan oleh sektor swasta dan koperasi, yaitu BUMN hadir untuk memenuhi kebutuhan-kebutuhan masyarakat baik barang maupun jasa dimana kebutuhan tersebut belum dapat dipasok oleh perusahaan swasta

5. Turut aktif memberikan bimbingan dan bantuan kepada pengusaha golongan ekonomi lemah, koperasi dan masyarakat dimana BUMN ikut serta dalam membangun perokonomian negara melalui ikut sertanya BUMN dalam memberikan partisipasinya terhadap Usaha Kecil Menengah (UKM).

Tujuan tersebut tentuanya sejalan dengan tujuan pemerintah dalam meningkatkan perekonomian Negara dan membantu berkembangnya perekonomian sector bawah. Selain itu BUMN dituntut untuk mengangkat perekonomian Negara dalam berbagai 
sector. Sean itunya adanya Badan Usaha Milik Daerah (BUMD) tidak sama dan tidak termasuk dalam ruang lingkup dari pengertian Badan Usaha Milik Negara (BUMN), hal ini disebabkan oleh adanya pengaturan yang bersifat khusus dan tata cara pendirian dan pertanggungjawaban yang diatur berbeda dalam peraturan tersendiri yaitu peraturan pemerintah daerah (KPPU, n.d.).

\section{b) Diselenggarakan oleh badan atau lembaga yang} dibentuk atau ditunjuk oleh pemerintah.

Pemerintah dalam pengertian dalam paraturan perundang-undangan merupakan pemerintah pusat yang terdiri atas presiden dan seluruh aparatur administrasi Negara tingkat pusat, maka dari itu badan atau lembaga yang dibentuk pemerintah merupakan badan atau lembaga yang ditetapkan dan diatur dalam peraturan perundang-undangan yang dibentuk pemerintah (KPPU, n.d.). Badan atau lembaga yang ditunjuk pemerintah harus memiliki beberapa cirri, antar lain:

a. Merupakan pemerintahan Negara

b. Berlandaskan manajemen keadministrasian Negara

c. Terdapat pengendalian dan pengawasan terhadap Badan Usaha Milik Negara (BUMN).

d. Bertujuan untuk tata usaha Negara

Berbeda denagan BUMN yang memiliki tujuan sesuai dengan UU, maka badan atau lembaga yang dibentuk pemerintah jika ditinjau dari pengertian pemerintah ini dalam menyelenggarakan monopoli atau pemusatan kegiatannya harus memenuhi bebrapa hal, antara lain pengelolaan dan pertanggungjawabn kegiatannya harus dipengaruhi, dibina dan dilaporkan pemerintah. Kedua jika BUMN harus mencari keuntungan maka badan atau lembaga yang dibentuk pemerintah ini tidak semata-mata ditunjuk untuk mencari keuntungan tetapi lebih ke pengoptimalan pelayanan kepada masyarakat. Dan yang ketiga badan atau lembaga yang dibentuk pemerintah ini tidak memiliki kewenangan melimpahkan seluruh atau sebagian monopoli atau pemusatan kegiatan kepada pihak lain. Walupun jika ditinjau dari segi tujuan BUMN dengan badan atau lembaga yang dibentuk pemerintah berbeda tetapi menurut UU diberi pengecualian untuk melakukan monopoli dan pemusatan kegiatan terhadap suatu barang dan jasa terkait untuk memenuhi hajat hidup orang banyak.

Jika ditinjau dari ulasan subtansi mengenai pasal 51 UU No 5 tahun 1999 tentang larangan praktik monopoli dan persaingan usaha tidak sehat, maka sebenarnya monopoli dan pemusatan kegiatan yang diberikan kepada BUMN dan badan atau lembaga yang ditunjuk oleh pemerintah tersebut tidak melanggar aturan UU No 5 tahun 1999, karena tujuan dari masingmasing badan atau lembaga dengan BUMN sejalan, yaitu sama-sama untuk meningkatkan perekonomian Indonesia, serta memberikan kemanfaatan bagi masyarakat. Namun justru dengan kegiatan monopoli dan pemusatan kegiatan tersebut tidak hanya meberikan dampak positif saja melain juga dampak negative bahwa pasar swasta tidak dapat masuk kedalamnya, sehingga kurang terciptanya pasar bebas. Selain itu subtasi-subtansi yang ada didalamnya pasal 51 yang sudah dijelaskan tersebut belum memberikan perincian yang jelas mengenai perusahaan mana yang diberikan pengecualian, karena dalam melakukan monopoli hanya ada satu perusahaan yang menguasainnya. Selain itu barang-barang atau jasa apa saja yang dikecualikan belum kongkrit di jelaskan, penjelasan diatas hanya menurut pendapat eneliti, sesuai dengan analisa dari beberapa sumber yang ada. Kurang jelasnya makna pasal tersebut dapat mengakibatkan perusahaan-perusahaan berlindung dibelakangnya.

\section{Pandangan Teori Hukum terhadap wewenang BUMN}

Berikut adalah pandan beberapa teori hukum mengenai wewenang BUMN terkait dengan kegiatan monopoli dana pemusatan kegiatan, jika ditinjau dari penjelasan diatas:.

\section{a. Teori Kepastian Hukum}

Hukum merupakan suatu aturan yang berlaku atau dituangkan dimasyarakat dengan bentuk suatu aturan, untuk mengatur segala pola perilaku masyarakat dalam bersosialisai atau bermasyrakat. Selain itu juga aturan yang ada atau yang berlaku harus mengikuti perkembangan zaman, semakin berkembangnya zaman maka semakin berkembang juga pola kehidupan manusia dalam mbermasyarakat. Hukum pada dasarnya bertujuan untuk memberikan keadilan dan 
kepastian, namun tidak selalu hukum memberikan keadilan bahkan kepastian. Kepastian hukum dapat diartikan ketekia seseorang dapat memperoleh suatu hal yang diharapkan pada saatt kondisi tertentu, kepastian dapat diartikan sebagi kejelasn norma sehingga dapat dijadikan pedoman bagi masyarakat yang dikenakan peraturan (Wijayanta, 2014). Selain itu kepastian hukum juga haru memiliki arti bahwa terdapat kejelasan dan ketegasan dalam berlakunya suatu aturan hukum yang ada dimasyrakat melalui pengaturan dalam Undang-undang yang tegas, jelas dan tidak mengandung arti lebih atau ganda atau berpeluang untuk ditafsirkan lain (Devano, 2016). selain itu pengertian kepastian hukum juga dapat dilihat dalam Undang-undang No 28 tahun 1999 tentang penyelenggaran negara yang bebas dari korupsi, kolusi dan neoptisme pasal 3 angka 1 menjelaskan bahwa;

"yang dimaksut dengan asas kepastian hukum asas dalam negara hukum yang mengutamakan landasan peraturan perundang-undangan, kepatutan dan keadilan dalam setiap kebijakan penyelenggaran negara" (Undang-undang No 28 tahun 1999 tentang penyelenggaran negara yang bebas dari korupsi, kolusi dan neoptisme).

Dalam pasal tersebut diartika bahwa, adanya asas kepastian hukum meberikan kepastian akan adanya suatu aturan yang ada dan memberikan keadilan bagi seluruh masyarakat serta pemerintah dalam melaksanakan tugasnya tidak boleh sewenang-wenang. Hukum yang berlaku di masyarakat harus memiliki kepastian hukum, jadi tidak hanya adil tetapi harus pasti. Tetapi terkandang suatu hukum sudah memberikan keadilan tetapi belum memberikan kepastian hukum. Selain itu kepastian hukum juga harus memiliki arti bahwa terdapat kejelasan dan ketegasan dalam berlakunya suatu aturan hukum yang ada dimasyrakat melalui pengaturan dalam Undangundang yang tegas, jelas dan tidak mengandung arti lebih atau ganda atau berpeluang untuk ditafsirkan lain (Devano, 2016). Jika ditinjau kembali adanya tauran pasal 51 tersebut menurut peneliti masih belum meberikan penjelas atau kepastian yang jelas mengenai maksut dari hal hal yang dikecualikan oleh pasal tersebut. Adanya aturan pasal 51 ini berawal dengan adanya kalimat mengenai "campur tangan Negara" dalam sekotor industri yang dimulai dengan istilah "dikuasai oleh Negara" yang dijelaskan pada pasal 33 Undang Undang Dasar 1945 yang menyatakan bahwa:

1) Perekonomian sebagai usaha bersama berdasar atas asas kekeluargaan

2) Cabang-cabang produksi yang pentingbagi Negara dan yang menguasai hajat hidup orang banyak dikuasai oleh Negara

3) Bumi dan air dan kekayaan alam yang terkandung didlamanya dikuasai oleh Negara dan dipergunakan untuk sebesar-besarnya kemakmuran rakyat

4) Perekonomian nasianl diselenggrakan berdasar atas demokrasi ekonomi dengan prinsip kebersamaan, efisiensi berkeadilan, berkelanjutan, berwawasan lingkungan, kemandirian serta dengan menjaga keseimbangankemajuan dan kesatuan ekonomi nasional

5) Ketentuan lebih lanjut mengenai pelaksanaan pasal ini diatur dalam undang-undang

Tetapai ada pendapat dari muhhamad hatta bahwa,pengertian dikuasai oleh Negara adalah dikuasai oleh Negara tidak berarti Negara sendiri menjadi pengusaha atau usahawan, lebih kongkritnya dijelaskan bahwa kekuasaan Negara terdapat pada membuat peraturan guna kelancaran jalan ekonomi, peraturan yang melarang terkait penghisapan orang yang lemah terhadap orang yang bermodal (Hatta, 1977). Selain itu juga terdapat putusan Mahkamah Konstitusi Nomor 111/PUU-XIII/2015 yang menyatakan bahwa maksut "penguasaan Negara" ditafsirkan MK bukan dalam makna Negara memiliki, tetapi dalam pengertian bahwa Negara hanya merumuskan mencakup aspek pengaturan, pengurusan, pengelolaan dan pengawasan . 3 Yang kedua hal tersebut telah dijelaskan pada permasalahan poin 1 dan poin 2. Dari kedua penjelasa tersebut sama-sama belum menjelaskan secara jelas mengenai hal-hal apa saja yang boleh dimonopoli dan pemusatan kegiatan oleh BUMN. Didalamya hanya menjelaskan maksut dari dikuasai Negara dan mengausai hajat hidup orang banyak. Dimana

\footnotetext{
${ }^{3}$ Dedy Ariayanto, Op Cit, hal 21
}

Analisis Yuridis Kewenangan Bumn Untuk Melakukan Monopoli dan atau Pemusatan Kegiatan dalam Perspektif Kepastian Hukum dan Kesejahteraan | 51 
penafsiran MK berbeda dengan penafisran KPPU. Dari penjelasan MK dalam kaitannya maksut hak menguasai Negara terhadap cabang-cabang yang penting dan menguasai hajat hidup orang banyak serta mencakup mengenai sumber daya alam, maka terdapat peluang bagi perorangan atau swasta untuk masuk kedalam dunia usaha terbut, asalkan lima peranan Negara atau pemerintah tetap terpenuhi, yaitu: ${ }^{4}$

1. Merumuskan kebijakan

2. Melakukan pengaturan

3. Melakukan pengurusan

4. Melakukan pengelolaan

5. Dan melakukan pengawasan

Selain itu MK juga berpendapat bahwa hal hal yang harus dikuasai Negara jika:

(i) Cabang-cabang produksi itu penting bagi Negara dan menguasai hajat hidup orang banyak

(ii) Penting bagi Negara tetapi tidak menguasai hajat hidup orang banyak

(iii) Tidak penting bagi Negara tetapi menguasai hajat hidup orang banyak

Sehingga Cabang produksi yang pada saat ini dinilai penting bagi Negara dan menguasai hajat hidup orang banyak pada lain waktu dapat berubah menajadi tidak penting dan tidak lagi menguasai hajat hidup orang banyak. Namun MK tidak menjelaskan secara terperinci hal-hal apa saja yang penting bagi Negara dan menguasai hajat hidup orang banyak.

Selain itu penafsiran dari KPPU, menfsirkan bahwa istilah menguasai Negara berarti Negara sepenuhnya memiliki dan memonopoli diamana didalamnya Negara mempunyai hak penuh. KPPU juga menafsirkan mengenai yang dimakust dengan cabang cabang produksi yang penting bagi Negara harus 2 sifat yaitu stratetgis dan finansial. Sedangkan hal-hal yang dimaksut dengan menguasai hajat hidup orag banyk harus memiliki 3 fungsi yaitu alokasi, distribusi dan stabilisasi. penafisran dari KPPU dan MK memang berbeda amun pada intiya sama yaitu untuk kemakmuran masyarakat. Tetapi dari kedua penafsiran tersebut sama-sama belum menjelaskan secara jelas apa saja hal-hal yang penting bagi Negara dan menguasai hajat hidup orang banyak. Sehingga hal ini menimbulkan tidak ada kepastian hukum, yang menimbulkan banyak penafsiran. Berarti secara tidak langsung juga jika pasal 51 berlandaskan pasal 33 maka dapat diartikan bahwa pasal 51 belum mencakup maksut dari pasal 33 UUD 1945. Maka dari itu penulis juga berpendapat secara tidak langsung dalam menafsirkan pasal 51 ini masih ambigu, dana masih dapat ditafsirkan secara luas. Tentunya adanya kepastian hukum itu sendiri sangat penting karena untuk memberikan kepastian jelas maksut dari adanya aturan yang dikeluarkan oleh pemerintah. Selain itu dalam hal ini wewenang BUMN diartikan sementara hanya sebagai pelaksana dari adanya perturan perundang-undnagan yang berlakuk, belum dijelaskan mengenai hal-hal apa saja yang boleh dimonopoli oleh BUMN itu sendiri.

\section{b. Teori Kesejahteraan Sosial}

Dalam kaitanya dengan pasal 51 maka tidak terlepas dari pasal 33 UUD 1945 yang tujuannya untuk meciptakan kesejahteraan sosial. Adanya pengaturan pasal 33, menunjukkan bahwa pasal tersebut tetap mengutamakan aspek kesejahteraan dan demokrasi ekonomi tanpa harus mendorong tumbuhnya ekonomi pasar dan kepemilikan hak property secara individual. Kesejahteraan merupakan bagian kesejahteraan yang memiliki arti terhadap suatu keadaan yang baik akan kehidupan masayarakat. Ada pendapat beberapa ahli mengenai pengertian kesejahteraan sosial, dimana menurut Walter Friendlander kesejahteraan sosial merupakan sebuah system yang terorganisir dari suatu institusi dan pelayanan social yang dirancang guna membantu individu atau kelompok dalam mecapai standart hidup yang lebih baik (Kurniawan, n.d.). Selain itu kesejahteraan dapat diartikan dalam beberapa hal (Kurniawan, n.d.):

1. Mencapai bagaimana kesejahteraan masyrakat itu sendiri.

2. Baik dibidang ekonomi pemberdayaan masyarakat yang dianggap satu kesatuan

3. Memiliki penyediaan layanan social dalam berbagai bidang untuk kepentingan seluruh masyarakat dan individu. 
4. Dalam kesejahteraan social juga digunakan sebagai disiplin akademik dalam penerapan ilmu sosiologi.

5. Kesejahteraan sosaian merupakan suatu kondisi dimana seseorang merasa nyaman. Damai, bahagia dana mampu memenuhi semua kebutuhan mereka dalam hidup bermsayarakat.

Kesejahteran sosial dapat diartikan sebagai suatu kondisi dalam suatu Negara yang berisi mengenai semua kegiatan masyarakat dalam memenuhi kehidupannya yang secara keseluruhan telah terpenuhi, selain itu kesejahteraan tersebut telah meliputi aspek kesehatan, keadaan ekonomi, kebahagiaan dan kualitas hidup rakyat. Kaitannya dengan pasal 51 maka jika dilihat dari penjelasan sebelumnya maka pertanyaan yang paling mendasar yaitu bagaimana pandangan teori kesejahteraan nasional dengan adanya pasal 51 terkait dengan wewenang BUMN. Apakah pasal 51 sudah dianggap mampu memenuhi kesejahteraan sosial. Dari penjelasan sebelumnya memang secara tidak langsung bahwa tujuan diberlakukannya pasal 51 yaitu sesuai dengan tujuan pasal 33 UUD 1945 yaitu tercantum pada alinea ke empat pembukaan UUD 1945, yang menyatakan:

"Kemudian daripada itu untuk membentuk suatu Pemerintah Negara Indonesia yang melindungi segenap bangsa Indonesia dan seluruh tumpah darah Indonesia dan untuk memajukan kesejahteraan umum, mencerdaskan kehidupan bangsa, dan ikut melaksanakan ketertiban dunia yang berdasarkan kemerdekaan, perdamaian abadi dan keadilan sosial, maka disusunlah Kemerdekaan Kebangsaan Indonesia itu dalam suatu Undang-Undang Dasar Negara Indonesia, yang terbentuk dalam suatu susunan Negara RepublikIndonesia yang berkedaulatan rakyat dengan berdasar kepada Ketuhanan Yang Maha Esa, Kemanusiaan yang adil dan beradab, Persatuan Indonesia dan Kerakyatan yang dipimpin oleh hikmat kebijaksanaan dalam Permusyawaratan/Perwakilan, serta dengan mewujudkan suatu Keadilan sosia! bagi seluruh rakyat Indonesia"

Tetapi denga masih belum adanya penafsiran yang jelas mengenai wewenang BUMN terkait dengan penerpana paal 51 dalam hal ini maka masyarakat akan dapat dirugikan.
Dengan adanya penelitian diatas maka penelitia berpendapat bahwa adanya pasal 51 kurang mampu memenuhi kesejahteraan masyarakat, salah satu hal yang dapat dikupas disini yaitu terkait dengan permainan tenaga kerja. Ketika suatu BUMN yang memiliki pengecualian untuk melakukan monopoli dan penguasaan, tidak memungkinan BUMN akan menjadi dekat dengan para petinggi pemerintahan. Sehingga hal itu mengakibatkan adanya hubungan timbal balik yang mampu mereka berikan terhadapa kedua belah pihak.

BUMN dalam melakukan perekrutan bisa jadi kurang transparan, perekrutan dilakukan secara umum tapi bisa saja kemungkinan terjadi putra putri dari para petinggi pemrintah yang direkrut, hal itu tanpa melihat kualitas dan kuntitas pekerja. Sehingga calon pekerja lain kemungkinan akan kalah dan otomatis langsung tergusur. Padahal dalam tujuan BUMN itu sendiri yaitu untuk merekrut tenag-tenaga kerja yang berkompeten. Hal itu tentunya telah menunjukkan salah satu dampak negative yang perlu diperhatikan. Maka dari itu ditinjau dengan era MEA ini, ketika system perekrutan tenaga kerja seperti ini maka akan mengakibatkan perusahaan BUMN tidak mampu bersaing karena memilki pegawai yang kurang kompeten. Padahal sudah dijelaskan juga pada Rencana Pembangunan Jangka Menengah Nasional (RPJMN) 2015 arah dan kebijakan strategi dari dialukakannya kualifikasi terhadap perekruan tenaga kerja yaitu:

1. Mampu meningkatkan kompetensi dan produktivitas tenaga kerja, sehingga para tenaga kerja harus mampu bersaing dengan pekerja lainnya tidak hanya dalam negeri tetapi juga luar negeri

2. Harus mampu memperbaiki iklim ketenagakerjaan dan menciptakan hubungan industrial yang jauh lebih baik.

Tentunya dengan kurang ketatnya dalam melakukan perekrutan tenaga kerja juga mengakibatkan suatu BUMN kurang inofatif, sehingga mengkibatkan BUMN kurang mampu besaing. Hal itu tentunya akan mempengaruhi kesejahteraan nasional, karena BUMN di era MEA yang menganut sistem persaingan bebas akan tertinggal dan kurang mampu berkembang serta mengakibatkan pertumbuhan ekonomi menurun. Selain itu BUMN yang merasa bahwa mereka 
mempunyai hak monopoli dan penguasaan atas suatu hal menurut peneliti mengakibatkan hala-hal yang menajdi sasaran dari Rencana Pembangunan Jangka Menengah Nasional (RPJMN) 2015 menjadi kurang terpenuhi. Diantaranya yaitu:

1. Dalam memberikan pelayanan publik BUMN akan kurang maksimal dikarenakan BUMN merasa mengusai dan banyak orang yang membutuhkan, hal itu menurut peneliti tidak hanya terjadi pada BUMN tetapi pada peayanan pemerintahan.

2. Kurang terselenggrannya BUMN dalam mendukung pertumbuhan dan penciptaan lapangan pekerja. Seperti yang sudah dijelaskan sebelumnya mengenai permainan tenaga kerja.

3. Kurang meningkatnya kapasitas BUMN, atau membesarkan perusahaan BUMN dalam meningkatkan daya saing BUMN, hal itu diakibatkan oleh kurang berinovasinya suatu BUMN .

Kaitannya dengan kesejahteraan sosial, memang secara langsung ada pasal 51 dalam tujuannya sesuai dengan pasal 33 UUD 1945 yaitu untuk meningkatkan kesejahteraan sosial, maka dalam hal ini perlu dilakukan peninjaunan kembali terhadap kaitannya apa saja yang dikecualikan dan dilarang dan hal-hal apa saja yang perlu diperhatikan oleh BUMN terhadapa kinerja BUMN itu sendiri.

\section{KESIMPULAN}

Dari penjelasan diatas maka peneliti menyimpulkan bahwa:

1. Wewenang BUMN dalam melakukan monopoli dan pemusatan kegiatan menurut MK hanya sebatas sebagai pelaksana dimana pemerintah yang mempunyai 5 peranan yaitu Merumuskan kebijakan, melakukan pengaturan, pengurusan, pengelolaan dan pengawasan tetapi tidak menutup kemungkinan untuk pihak swasta masuk kedalamya. Walaupun secara tegas belum dijelaskan mengenai hal-hal apa yang penting bagi Negara dan menyangkut hajat hidup orang banyak. Sehingga dalam hal ini belum jelas mengenai hal-hal apa saja yang boleh di monopoli oleh BUMN.

2. Wewenang BUMN dalam melakukan monopoli dan pemusatan kegiatan menurut KPPU, menjelaskan bahwa BUMN yang memperoleh mandat oleh Undang-undang untuk melakukan monopoli terhadap suatu kegiaan usaha. KPPU juga tidak menafsirkan secara jelas mengenai hal-hal apa saja yang boleh di monopoli oleh BUMN.

3. Adanya penafsiran oleh MK dan BUMN yang belum meberikan penjelasan secara jelas mengenai hal-hal yang penting bagi Negara dan menyangkut hajat hidup orang banyak mengakibatkan kurang adanya kepastian hukum dan belum terselenggara sepenuhnya kesejahteraan social, akibat dari multi tafsir dari pasal 51

\section{SARAN}

Segera dilakukan peninjauan kembali terkait pasal 51 Undang-undang No 5 tahun 1999 tentang larangan pratik monopoli dan persaingan usaha tidak sehat, mengenai hal-hal yang dikecualikan dan perlu ditetapkannya suatu prodak hukum mengenai hal-hal yang penting bagi Negara serta menyangkut hajat hidup orang banyak, sehingga adanya suatu aturan akan memberikan satu penafsiran dan memberikan kepastian hukum.

\section{REFERENSI}

Anggraini, A. . T. (2010). Aspek Monopoli Atas Cabang Produksi Yang Menguasai Hajat Hidup Orang Banyak Berdasarkan Hukum Persaingan Usaha. Jurnal Hukum Prioris, 2(4).

Ansari, M. I. (2017). Badan Usaha Miliki Negara dan Kewajiban Pelayanan Umum Pada Sektor Pos. Jurnal Penelitian Pos Dan Informatika, 8(1), 112.

Arif, A., \& Ukasa, H. (2010). Analisa Kinerja Keuangan Badan Usaha Milik Negara (BUMN) Pasaca Privatisasi. Jurnal Informasi Perpajakan Jurnal Akuntansi Keuangan Publik, 5(1).

Asshiddiqie, J. (1996). Pembaharuan Hukum Pidana : Studi tentang Bentuk-bentuk Pidana dalam Tradisi Hukum Fiqh dan Relevansinya Bagi Usaha Pembaharuan KUHP Nasional. Bandung: Angkasa.

Devano, S. (2016). Penilaian terhadap kesesuaian atau penetapan bea keluar atas ekspor mineral dengan asas kepastian hukum dan asas ekonomis. Jurnal Mimbar Hukum, 28(1). 


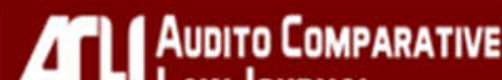

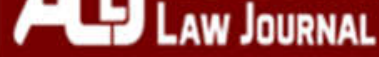

Enggi Syefira Salsabila pp. 38-55
Hatta, M. (1977). Penjabaran Pasal 33 Undang Undang Dasar 1945. Jakarta: Mutiara.

KPPU. (n.d.). Pedoman Pelaksanaan pasal 51 Undang-undang no 5 tahun 1999 tentang praktik monopoli dan persaingan usaha tidak sehat.

Kurniawan, A. (n.d.). Definisi, Pengertian Kesejahteraan Sosial Menurut Para Ahli. Retrieved March 13, 2019, from www.gurupendidikan.com

Magnar, K., Junaenah, I., \& Taufik, G. A. (2010). Tafsir MK atas pasal 33 UUD 1945 (study atas putusan MK mengenai Judicial Review NN No 7 tahun 20014, UU No 22 tahun 2001 dan UU No 20 tahun 2002. Jurnal Konstitusi, 7(1).

Malaka, M. (2014). Praktek Monopoli dan Persaingan Usaha, Jurnal Syariah dan Ekonomi Islam. Fakultas Hukum-STAIN Kendari, 7(2).

Mertokusumo, S. (2009). Asas Legalitas dan Penemuan Hukum dalam Hukum Pidana. Yogyakarta: Erlangga.

Peter Mahmud Marzuki. (2009). Penelitian Hukum, Edisi Pertama Cetakan Kelima. Jakarta: Kencana.

Saifullah. (2004). Konsep Dasar Metode Penelitian Dalam Proposal Skripsi. UIN Malang.

Tarigan, A. A. (2016). Praktek Monopoli dan Persaingan Usaha Tidak Sehat dalam Prespektif Hukum Ekonomi dan Hukum Islam. Journal of USU International Law, 9(1).

Toersian, T. O., \& Haryani, A. T. (2012). Pengecualian Monopoli dan/atau Pemusatan Kegiatan Badan Usaha Milik Negara (BUMN) Dalam Prespektif Hukum Persaingan Usaha. Jurnal Hukum, 13(2).

Wijayanta, T. (2014). Asas Kepastian Hukum, Keadilan, dan Kemanfaatan Dalam Kaitannya dengan Putusan Kepailitan Pengadilan Niaga. Jurnal Dinamika Hukum, 14(1).

Yani, A., \& Widjaja, G. (1999). Anti Monopoli. Jakarta: Radja Grafindo Persada.

Yusroni, Nanang, D. T. R. (2007). Privatisasi Badan Usaha Milik Negara (BUMN), Eksistensi dan Kinerja Ekonomi Nasional Dalam system
Ekonomi Pasar. Jurnal Ekonomi Dan Bisnis, 2(1), 73. 